\title{
Jaringan Komunikasi Antara Pimpinan dan Karyawan dalam Menumbuhkan Komitmen Karyawan di PT. Digital Suplai Indonesia
}

\author{
Sharleen Oktaviana, Widayatmoko \\ sharleenoktaviana97@gmail.com,widayatmoko@fikom.untar.ac.id
}

Fakultas Ilmu Komunikasi Universitas Tarumanagara

\begin{abstract}
Every company must have a different communication network. This research was conducted to find out the communication network between leaders and employees at PT Digital Suplai Indonesia. Communication networks can be seen from the communication between leaders and employees. In this research, we see networks of information flowing from one person to another. This study also shows people who are dominant in an organization group. The theory used is Abdullah Masmuh's theory that there are five communication networks, namely circles, wheels, $Y$, chains, and all channels. This study used a qualitative approach with in-depth interview techniques on six informants. Data collection in this study was carried out by conducting observations to see the direct communication between leaders and employees. In addition, there is also documentation in the form of the company structure under study. The results of the research at PT. Digital Suplai Indonesia shows there are two types of communication networks that occur namely star networks or all channels and wheel networks.
\end{abstract}

Keywords: organizational communication, network communication

\begin{abstract}
Abstrak
Setiap perusahaan pasti mempunyai jaringan komunikasi yang berbeda-beda. Penelitian ini dilakukan untuk mengetahui jaringan komunikasi antara pimpinan dan karyawan di PT Digital Suplai Indonesia. Jaringan komunikasi dapat dilihat dari komunikasi yang terjalin antara pimpinan dan karyawan. Dalam penelitian ini terlihat jaringan-jaringan aliran informasi dari satu orang ke orang lain. Penelitian ini juga menunjukkan orang-orang yang dominan dalam suatu kelompok organisasi. Teori yang digunakan adalah teori Abdullah Masmuh yang terdapat lima jaringan komunikasi yaitu lingkaran, roda, Y, rantai, dan semua saluran. Penelitian ini menggunakan pendekatan kualitatif dengan teknik wawancara mendalam pada enam orang informan. Pengumpulan data pada penelitian ini dilakukan dengan melakukan observasi untuk melihat langsung komunikasi yang terjalin antara pimpinan dan karyawan. Selain itu juga ada dokumentasi berupa struktur perusahaan yang diteliti. Hasil penelitian di PT. Digital Suplai Indonesia menunjukkan terdapat dua jenis jaringan komunikasi yang terjadi yaitu jaringan bintang atau semua saluran dan jaringan roda.
\end{abstract}

Kata Kunci: komunikasi organisasi, jaringan komunikasi

\section{Pendahuluan}

Komunikasi saat ini sangat diperlukan dimanapun kita berada. Walaupun terlihat mudah tetapi banyak permasalahan yang timbul akibat komunikasi yang tidak baik atau salah pengertian terhadap satu sama lain. Dalam sebuah organisasi 
banyak terjadi komunikasi antara atasan dan bawahan maupun komunikasi antar sesama anggota lainnya. Terjadinya salah paham akibat pesan yang diterima tidak tepat atau tidak sesuai dengan seharusnya menjadikan organisasi tidak berjalan dengan baik. Pertukaran pesan ini melalui jalan tertentu yang dinamakan jaringan komunikasi. Setiap perusahaan mempunyai jaringan komunikasinya masing-masing. Penggunaan jaringan komunikasi ini menentukan intensitas komunikasi dan interaksi sosial antara anggota organisasi. Intensitas komunikasi dan interaksi sosial dapat diliat dari seberapa banyaknya komunikasi yang dilakukan oleh satu anggota terhadap anggota lainnya. Tingkat intensitas dan interaksi sosial yang terjadi diprediksikan dapat melihat aliran informasi yang terjadi diperusahaan

Permasalahan yang terjadi ini menarik perhatian penulis untuk mengkaji lebih dalam tentang penggunaan jaringan komunikasi yang digunakan pada organisasi tentunya berbeda dari organiasasi lainnya. Selain itu jaringan komunikasi ini dapat menumbuhkan komitmen yang membuat anggota organisasi tetap berada dalam lingkup organisasi tersebut. Berdasarkan pembahasan masalah di atas maka permasalahan dalam penelitian ini adalah bagaimana jaringan komunikasi dalam perusahaan di PT. Digital Suplai Indonesia. Tujuan dari penelitian ini yaitu untuk mengetahui jaringan komunikasi yang digunakan di PT. Digital Suplai Indonesia.

Berikut akan dijelaskan beberapa konsep yang digunakan dalam penelitian ini. Pertama adalah teori komunikasi, menurut Ricard West dan Lynn H. Turner (2008) komunikasi (communication) merupakan sebuah proses pertukaran psan yang menggunakan sebuah simbol untuk mendapatkan makna pesan yang sesuai dari pengirim ke penerima pesan. Terdapat dimensi-dimensi komunikasi dalam kehidupan organisasi menurut Ngalimun (2017), ada komunikasi internal dan eksternal. Dalam komunikasi internal perusahaan berfungsi untuk menyampaikan pesan antara anggota-anggota organisasi yang terjadi untuk kepentingan organisasi, seperti komunikasi antara pimpinan dengan bawahan antara sesama bawahan, dsb. Komunikasi internal ini lazim dibedakan menjadi dua, yaitu: komunikasi vertikal dan horizontal. Komunikasi vertikal, yaitu komunikasi dari atas ke bawah dan dari bawah ke atas. Dalam komunikasi vertikal, pimpinan memberikan intruksi-intruksi, petunjuk-petunjuk, informasi-informasi, dll kepada bawahan. Sedangkan bawahan memberikan laporan-laporan, saran-saran, pengaduan-pengaduan, dan sebagainya kepada pimpinan. Komunikasi horizontal atau lateral, yaitu komunikasi antara sesama seperti dari karyawan kepada karyawan, manajer kepada manajer.

Pertukaran pesan dalam organisasi melalui jalan tertentu yang dinamakan pola aliran informasi atau jaringan komunikasi. Menurut Abdullah Masmuh (2008) lima pola aliran komunikasi diantaranya yaitu pola lingkaran, roda, Y, rantai, dan semua saluran. Pola lingkaran tidak memiliki pemimpin sehingga semua anggota posisinya sama. Mereka memiliki wewenang atau kekuatan yang sama untuk mempengaruhi kelompok. Setiap anggota bisa berkomunikasi dengan dua anggota lain disisinya. Pola roda memiliki pemimpin yang jelas, yaitu yang posisinya di pusat. Orang ini merupakan satu-satunya yang dapat mengirim dan menerima pesan dari semua anggota. Oleh karena itu, jika seorang anggota ingin berkomunikasi dengan anggota lain, maka pesannya harus disampaikan melalui pemimpinnya. Pola Y relatif kurang tersentralisasi dibanding dengan pola roda, tetapi lebih tersentralisasi dibanding dengan pola lainnya. Pada pola Y juga terdapat pemimpin yang jelas. Anggota ini dapat mengirimkan dan menerima pesan dari dua orang lainnya. Ketiga anggota lainnya komunikasinya terbatas dengan satu orang lainnya. Pola rantai sama dengan pola lingkaran kecuali bahwa para anggota yang paling ujung hanya dapat 
berkomunikasi dengan satu orang saja, keadaan terpusat juga terdapat disini. Orang yang berada di posisi tengah lebih berperan sebagai pemimpin daripada mereka yang berada di posisi lain. Pola semua saluran atau pola bintang hampir sama dengan pola lingkaran dalam arti semua anggota adalah sama dan semuanya juga memiliki kekuatan yang sama untuk mempengaruhi anggota lainnya. Akan tetapi, dalam struktur semua saluran, setiap anggota bisa berkomunikasi dengan setiap anggota lainnya. Pola ini memungkinkan adanya partisipasi anggota secara optimum.

\section{Metode Penelitian}

Pendekatan penelitian yang dilakukan berupa penelitian kualitatif karena penelitian ini mendapatkan datanya berupa kata-kata tertulis atau lisan dan mempertimbangkan pendapat orang lain yaitu narasumber. Metode penelitian yang digunakan peneliti adalah studi kasus. Studi kasus menurut Guba \& Lincoln, lebih diperjelas oleh Stake, kemudian dikembangkan oleh Creswell (dalam Gunawan, 2014), yang menyatakan bahwa penelitian studi kasus yang dilakukan terhadap suatu objek yang ingin diteliti, yang disebut sebagai kasus. Studi kasus yang dikaji oleh peneliti mengenai kasus jaringan komunikasi antara pimpinan dan karyawan di PT. Digital Suplai Indonesia. Dengan mempelajari aspek individu, kelompok, dan peristiwa ini dapat dianalisis secara lengkap, dan secara mendalam tentang subjek yang akan diteliti. Subjek penelitian ini adalah pimpinan dan karyawan perusahaan PT. Digital Suplai Indonesia. Objek penelitiannya merupakan jaringan komunikasi organisasi dan komitmen karyawan. Metode pengumpulan data yang peneliti gunakan dengan wawancara mendalam enam narasumber yang merupakan bagian dari PT. Digital Suplai Indonesia, observasi dengan melihat komunikasi yang berlangsung antara pimpinan dan karyawan di perusahaan yang ingin diteliti, dan melakukan penelaahan dokumentasi seperti sejarah lembaga dan struktur organisasi PT. Digital Suplai Indonesia.

\section{Hasil Penemuan dan Diskusi}

\section{Komunikasi Internal Organisasi}

Komunikasi Vertikal

Komunikasi vertikal ke bawah dan vertikal ke atas yang baik diperlukan untuk menjaga komunikasi antara karyawan dengan pimpinan sehingga terhindar dari kesalahpahaman. Komunikasi vertikal ke bawah lebih kepada komunikasi pesan dari pimpinan ke karyawan berupa instruksi perintah, anggaran yang disetujui atau tidak, pernyataan kebijakan, variasi dalam standar prosedur operasi, laporan kegiatan dari tugas yang diberikan, dan mencatat perubahan-perubahan lainnya. Sedangkan Komunikasi vertikal ke atas lebih kepada komunikasi yang mengalir dari bawah ke atas yaitu dari karyawan ke pimpinan langsung. Pada komunikasi vertikal ke atas mengutamakan mengkomunikasikan pesan berupa tanggungjawab tugas, menjalankan perintah dan instruksi yang diberikan pimpinan kepada karyawan.

Komunikasi yang terjadi di perusahaan ini terjalin dengan baik. Pesan yang disampaikan dapat langsung disampaikan ke atasan. Manager office dan kepala perdivisi hanya bertugas memantau kelancaran tugas yang ada dan memberi solusi jika ada kendala. Tidak terbatasnya komunikasi membentuk kenyamanan mereka saat berkomunikasi dengan pimpinan sehingga mereka bisa menyatakan pendapat mereka. Komunikasi yang baik juga meminimalisir adanya kendala dalam 
penyampaian pesan dalam organisasi. Kendala dari komunikasi yang terjadi di perusahaan dikarenakan semua keputusan terpusat pada pimpinan teratas. Semua keputusan terpusat pada satu pimpinan. Anggota karyawan tidak dapat memutuskan sendiri kebijakan yang ada. Lamanya proses pengambilan keputusan ini menghambat jalannya kegiatan perusahaan sehingga tidak efektif waktu dalam menyelesaikan masalah yang terjadi didalam perusahaan.

\section{Komunikasi horizontal}

Komunikasi horizontal terjadi antar rekan kerja yang setingkat. Komunikasi yang terjadi dengan sesama karyawan sangat baik. Tidak ada batasan komunikasi antara satu divisi dengan divisi lainnya. Karyawan dapat berkomunikasi dengan karyawan divisi lain tanpa perlu ada penghubung. Dalam hal penyampaian informasi lebih efektif karena pesan bisa disampaikan langsung dan pihak yang menerima pesan bisa memahami maksud dari karyawan yang menyampaikan pesan. Selain itu semua karyawan berkomunikasi tidak monoton soal pekerjaan saja tetapi ada candaan dalam berkomunikasi.

\section{Jaringan Komunikasi}

Peneliti menemukan bahwa komunikasi yang terjadi di perusahaan ini terdapat satu pimpinan yang bertugas mengatur jalannya perusahaan sehingga semua keputusan harus dibuat dan diketahui oleh pimpinan. Tetapi pimpinan tidak menutup partisipasi setiap karyawan untuk menyatakan pendapatnya terkait kebutuhan perusahaan. Pemimpin tersebut dapat berhubungan dengan semua anggota kelompok. Seringkali pimpinan mengikutsertakan semua karyawan dari berbagai divisi dalam rapat guna mendapatkan saran dan evaluasi yang baik untuk perusahaan kedepannya.

Semua karyawan dari semua divisi dapat berkomunikasi dengan semua karyawan walaupun berasal dari divisi yang lain. Komunikasi yang terbentuk memberikan kepuasan kepada semua karyawan untuk berkomunikasi kepada siapapun, dan dapat bermusyawarah kepada semua karyawan untuk menyelesaikan tugas bila tugas berkenaan dengan masalah yang sukar. Komunikasi antara karyawan dan pimpinan tidak ada batasan sehingga mereka bisa berkomunikasi langsung kepada pimpinan di perusahaan ini. Sebagai karyawan mereka juga dapat ikut berpartisipasi dalam pengambilan keputusan perusahaan dalam batasan tertentu sesuai dengan tugas dari divisi masing-masing. Komunikasi yang terjadi membuka peluang kesempatan bagi setiap karyawan ikut berpartisipasi dalam menyatakan pendapat mereka.

Jaringan komunikasi yang digunakan oleh perusahaan PT. Digital Suplai Indonesia ada dua jenis jaringan yaitu pola jaringan semua saluran atau bintang dan pola jaringan roda. Dalam perusahaan ini, pola semua saluran atau bintang dapat terlihat dari komunikasi yang terjadi tidak membutuhkan perantara orang dalam menyampaikan pesan. Komunikasi yang terjalin dalam perusahaan bersifat terbuka. Pesan dapat disampaikan langsung kepada pimpinan dan pesan dapat langsung diberikan kepada sesama karyawan. Tidak ada hierarki yang rumit sehingga semua anggota organisasi dapat berkomunikasi kepada siapapun dan kapanpun. Pola ini juga terlihat dari adanya musyawarah yang terjadi dalam perusahaan. Setiap karyawan punya andil dalam mengambil keputusan sesuai dengan tugas-tugas mereka. Mereka juga dapat menyatakan pendapat dan memberikan saran langsung kepada sesama karyawan maupun kepada pimpinan langsung. 
Pola jaringan roda dapat dilihat dari adanya pimpinan yang jelas untuk memberikan instruksi, perintah, dan mempunyai wewenang dalam menentukan semua keputusan yang ada. Posisi pemimpin di perusahaan membuat informasi yang paling banyak diketahui adalah informasi yang dimiliki pimpinan. Semua kegiatan yang berjalan dan dilaksanakan setiap karyawan perusahaan harus diketahui oleh pimpinan. Ada beberapa bentuk pesan yang komunikasi harus melewati pimpinan dahulu tetapi hanya untuk keadaan-keadaan tertentu yang bilamana seseorang itu tidak mempunyai wewenang terkait dengan kebjikan dalam divisinya. Karyawan juga tidak dapat mengambil keputusan yang beresiko tinggi bagi perusahaan. Hanya keputusan-keputusan kecil dan itu hanya terkait dengan jobdesk yang diberikan. Fokus perhatian dari pola ini adalah seseorang (pemimpin). Apakah pemimpin tersebut dapat berhubungan dengan semua anggota kelompok, dan tidak ada masalah komunikasi, waktu dan feedback dari anggota kelompok.

Jaringan juga mempunyai aliran yang menghubungkan semua aktor dalam jaringan. Aktor satu mungkin tidak mempunyai link dengan aktor satunya, tetapi jaringan menyediakan alur (arus) yang memungkinkan semua aktor terhubung satu sama lain.

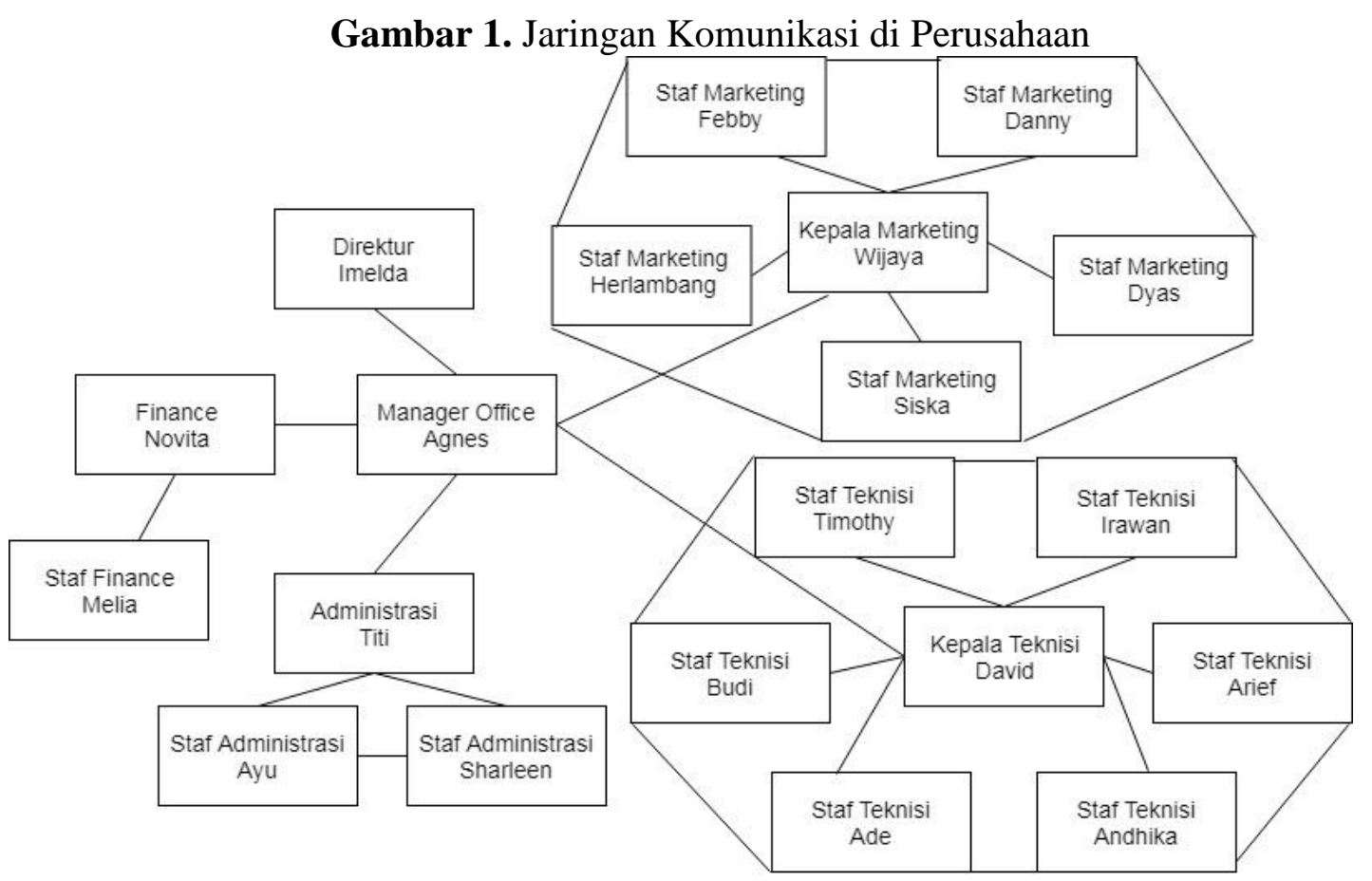

Dalam perusahaan terdapat peranan dalam masing-masing karyawan dalam perusahaan. Berdasarkan struktur perusahaan dapat diuraikan peranan dari setiap karyawan. Dari hasil penelitian ini, peneliti menemukan bahwa komunikasi yang terjadi di perusahaan ini terdapat satu pimpinan yang bertugas mengatur jalannya perusahaan sehingga semua keputusan harus dibuat dan diketahui oleh pimpinan yaitu jabatan Direktur. Disini Direktur menjadi satu-satunya orang yang paling dominan diantara yang lainnya. Ia berperan sebagai pemimpin pendapat dan penentu seluruh kebijakan yang ada diperusahaan. Manager office berperan sebagai penghubung antara Direktur dan kepala per divisi kelompok kerja. Ia berperan dalam mengawasi jalannya kegiatan perusahaan yang dilakukan oleh kepala divisi dan anggota-anggotanya. Terdapat tiga kepala divisi yaitu bagian finance, marketing, dan 
teknisi. Setiap kepala berperan menggerakkan anggota-anggotanya untuk bekerja. Bagian finance, kepala marketing, dan kepala teknisi berperan sebagai jembatan yang menjembatani komunikasi antara anggota-anggota staf mereka dengan atasan yaitu manager office. Mereka bertugas mengawasi bawahan mereka dalam bekerja dan memberikan laporan rutin pada atasan mengenai kinerja yang dilakukan. Mereka dapat saling bertukar informasi dan saling membantu menyelesaikan tugas berkaitan dengan divisi masing-masing. Sisanya adalah karyawan berperan sebagai staf yang menjalankan perintah yang diberikan pimpinan diatasnya. Staf diperusahaan memiliki kuasa paling kecil dalam hal pengambilan keputusan. Mereka semua berkerja berdasarkan perintah yang diberikan oleh pimpinan mereka.

\section{Simpulan}

Berdasarkan hasil analisis data yang telah peneliti lakukan, maka dapat disimpulkan bahwa jaringan komunikasi yang digunakan PT. Digital Indonesia yaitu jaringan semua saluran atau bintang dan roda. Pola semua saluran terlihat pada komuniaksi sesama karyawan terbuka. Pola roda terlihat pada adanya pemimpin yang jelas untuk mengatur dan mengetahui semua yang terjadi dalam perusahaan. Individu yang paling dominan dalam perusahaan adalah Direktur yang merupakan pemimpin pendapat. Manager office berperan sebagai penghubung, kepala per divisi berperan sebagai jembatan, dan staf berperan sebagai anggota klik yang membantu menjalankan kegiatan perusahaan secara keseluruhan.

\section{Ucapan Terima Kasih}

Penulis mengucapkan terima kasih kepada pihak-pihak yang telah membantu dalam proses penelitian hingga dipublikasikan, terutama kepada narasumber yang telah bersedia meluangkan waktu untuk kerjasamanya selama proses penelitian ini berlangsung.

\section{Daftar Pustaka}

Eriyanto. (2014). Analisis Jaringan Komunikasi Strategi Baru dalam Penelitian Ilmu Komunikasi dan Ilmu Sosial Lainnya. Jakarta: Prenadamedia Group.

Gunawan, Imam. (2014). Metode Penelitian Kualitatif: Teori dan Praktik. Jakarta: Bumi Aksara.

Masmuh, Abdullah. (2008). Komunikasi Organisasi Dalam Perspektif Teori Dan Praktek. Malang: UMM Press.

Ngalimun. (2017). Ilmu Komunikasi Sebuah Pengantar Praktis. Yogyakarta: Pustaka Baru Press.

Ruslan, Rosady. (2017). Metode Penelitian: Public Relation \& Komunikasi. Jakarta: Rajawali Pers.

West, R., \& Lynn H. Turner. (2008). Pengantar Teori Komunikasi Analisis dan Aplikasi (Edisi 3). Jakarta: Salemba Humanika.

Wibowo. (2017). Perilaku Dalam Organisasi (Edisi Ketiga). Depok: PT RajaGrafindo Persada. 